\title{
Rapid and Low Cost Determination of Cadmium in Whole Blood by Hydride Generation Atomic Fluorescence Spectrometry after Ultrasound-Assisted Sample Preparation
}

\author{
Zhongxi Li*,a and Liping Zhou ${ }^{b}$ \\ ${ }^{a}$ The Research Center of Analytical Technique \& Instrument, Northwest Geological Research Institute, \\ No. 25, Xiying Road, Xi'an, 710054, P.R. China \\ ${ }^{b}$ Analytical \& Testing Center, Northwest Geological Research Institute, \\ No. 25, Xiying Road, Xi'an, 710054, P.R. China
}

\begin{abstract}
Foi desenvolvido um método rápido, de baixo custo e preciso para a determinação de cádmio em sangue integral usando espectrometria de fluorescência atômica com geração de hidreto (HG-AFS). A amostra foi preparada por lixiviação assistida por ultra-som e a solução resultante foi usada diretamente para a determinação do cádmio por HG-AFS. Adotando-se as condições otimizadas para o procedimento proposto, o limite de detecção (LOD) e limite de quantificação (LOQ) foram de 0,08 e $0,26 \mu \mathrm{g} \mathrm{L}^{-1}$, respectivamente, calculados a partir de três e dez vezes o desvio padrão de onze medidas para a amostra de sangue bovino (branco), com baixo teor de $\mathrm{Cd}$ $\left(0,2 \mu \mathrm{g} \mathrm{L} \mathrm{L}^{-1}\right.$, diluída por um fator de 10$)$. O desvio-padrão relativo (RSD, $\left.n=7\right)$ variou entre 3-10\% (entre medidas) para amostras de sangue contendo de 1 a $8 \mu \mathrm{g} \mathrm{L}^{-1}$ de cádmio. A precisão e aplicabilidade prática do método foram comprovadas analisando-se materiais de referência certificados (MRCs). Os resultados foram ainda comparados com aqueles obtidos por espectrometria de massa com fonte de plasma indutivamente acoplado (ICP-MS). Uma boa concordância foi observada entre os resultados obtidos por HG-AFS e ICP-MS para a determinação de cádmio em MRCs e em amostras de sangue humano.
\end{abstract}

A rapid, low cost and precise method was developed for the determination of cadmium in whole blood using hydride generation atomic fluorescence (HG-AFS). Sample was simply prepared utilizing ultrasound-assisted leaching and the resulting solution was directly used for cadmium determination by HG-AFS. Adopting optimized conditions, the limit of detection (LOD) and limit of quantification (LOQ) of the proposed procedure were 0.08 and $0.26 \mu \mathrm{g} \mathrm{L}^{-1}$, calculated from three and ten times the standard deviations of eleven runs of blank blood sample (bovine blood) with low Cd content $\left(0.2 \mu \mathrm{g} \mathrm{L}{ }^{-1} \mathrm{Cd}\right.$, tenfold diluted); and the relative standard deviation (RSD, $n=7$ ) varied between $3-10 \%$ (between-run) at $1-8 \mu \mathrm{g} \mathrm{L} \mathrm{L}^{-1}$ cadmium level in blood. The accuracy and practical applicability of the method were validated by analyzing certified reference materials (CRMs) and further demonstrated by results comparison with inductively coupled plasma masss spectrometry (ICP-MS). Good agreement has been demonstrated between results obtained by HG-AFS and ICP-MS for cadmium determination in CRMS and human whole blood.

Keyword: blood cadmium, ultrasound-assisted extraction, hydride generation, atomic fluorescence spectrometer

\section{Introduction}

As an environmental pollutant, cadmium (Cd) can give rise to a number of adverse health effects. Toxicological effects of cadmium compounds on both animal and human life have long been recognized. The toxic effects of cadmium are due to its inhibition of various enzyme

*e-mail: Lizhongxi8@163.com systems, it is able to inactivate enzymes containing sulphydryl groups and it can also produce uncoupling of oxidative phosphorylation in mitochondria. In humans, the largest amounts of cadmium are deposited in the kidney, liver or bone damage, ${ }^{1,2}$ and several observations suggest that cadmium may be a cause of renal cancer. ${ }^{3}$ The International Agency for Research on Cancer (IARC) has also classified cadmium and cadmium compounds as carcinogenic to humans. ${ }^{4}$ The environmental and clinical 
importance of cadmium has generated a considerable interest in the development of reliable analytical methods to quantify cadmium in whole blood.

The determination of cadmium in blood poses several problems mainly due to the low concentration, the great variation of matrix from sample to sample and the contamination. The ideal methods would require minimal sample handling and have low detection limits. Among the various spectrometric techniques available for the determination of cadmium, electrothermal atomic absorption spectrometry (ETAAS) $)^{5-8}$ and inductively coupled plasma mass spectrometry (ICP-MS) ${ }^{9-11}$ are the most commonly used techniques, because of their high sensitivities, excellent detection limit and easy sample handling. However, either the cost of the commercial instruments or their operations may go beyond the acceptable limit for large scale screening in clinical laboratories. In addition, ETAAS signal is sensitive to the composition of the matrix and thus creates a serious matrix effect; and the intrinsic low tolerance limit to total dissolved solids restricts the direct applications of ICP-MS for determining cadmium in whole blood.

In clinical analysis, not only there are needs for greater reliability, greater robustness, and higher throughput, but also there are requirements for lower cost and lower detection limit. The non-dispersive atomic fluorescence spectrometry (AFS) is most suitable for measuring hydrideforming elements because of its high sensitivity, wide linear dynamic range, speed of analysis, ease of use, and low cost. The cost of acquiring an AFS instrument is only about one fourth compared to an ETAAS and one fifteenth of an ICP-MS; and the costs of its maintenance and operation are markedly lower than those of ETAAS and ICP-MS. At the same time, the technique can obtain excellent detection limits for the determination of hydride-forming elements. ${ }^{12-14}$ Recently, several hydride generation systems coupled with non-dispersive AFS have been developed for the determination of trace amounts of cadmium in various sample type ${ }^{15-20}$ and become one of the most sensitive methods for the determination of traces of cadmium.

The application of direct hydride generation AFS in blood analysis is limited because of strong interference; most of the sample digestion methods for various clinical samples are largely limited to the conventional acid (e.g. $\mathrm{HNO}_{3}, \mathrm{HClO}_{4}$ ) digestion procedures with different heating systems. But most of these digestion procedures are somewhat limited by various primary factors including long dissolution times, potential loss of volatile elements, high analytical blanks due to excessive amounts of reagents contaminants, etc. In contrast to conventional sample preparation methods, ultrasound-assisted leaching is an expeditious, inexpensive, efficient alternative to conventional extraction technique and has been applied to both organic and inorganic analytes in a wide variety of samples. ${ }^{21,22}$ Additionally, ultrasonic extractions have proved to be successful for achieving quantitative recoveries of cadmium from various biological matrices. ${ }^{23-27}$

The aims of this study was to evaluate the possibility of applying diluted acid as extractant for the full extraction of cadmium from whole blood utilizing ultrasound-assisted leaching and develop a simple and rapid method for the direct determination of cadmium in blood by HG-AFS in the extracted solution, without any further sample treatment. The different sonication parameters have been optimized in order to obtain the maximum extraction efficiency for cadmium. Chemical conditions have also been adjusted taking into account the modifications of the intermittent-flow reactor. To the authors' best knowledge, this is the first report of systematic use of HG-AFS for the determination of cadmium in blood after ultrasoundassisted sample preparation.

\section{Experimental}

\section{Reagents and chemicals}

Cadmium standard solution (1000 $\mathrm{mg} \mathrm{L}^{-1}$ ) was obtained from National Standard Material Center of China. Reference standard solutions were daily prepared by appropriate dilution of the stock solution. Antifoam B emulsion from Sigma (Germany) was used. Thiourea and all mineral acids used were obtained from Xi'an Chemical Reagents Co. Aqueous solutions of potassium tetrahydroborate $\left(\mathrm{KBH}_{4}\right)$ were daily prepared by dissolving the solid reagent in $2 \mathrm{~g} \mathrm{~L}^{-1} \mathrm{KOH}$ plus $0.01 \%$ (v/v) antifoam "B". A $1.5 \%$ (m/v) solution of thiourea, in the presence of $1 \mathrm{mg} \mathrm{L}^{-1} \mathrm{Co}$ (prepared from a $1000 \mathrm{mg} \mathrm{L}^{-1}$ stock standard solution), catalysed the formation of volatile species of $\mathrm{Cd}$ by hydride generation. All chemicals used were of the highest purity grade reagents. All glassware and plasticware was washed with nitric acid and rinsed with ultra-pure water. Ultra-pure water obtained using a Milli-Q system (Millipore), was used throughout.

Whole blood certified reference materials (CRMs) GBW 09132, GBW09133 and GBW09134 from National Standard Material Center of China were used for optimizing the sonication parameters and validating the developed method.

A bovine whole blood was collected from one year old calves. Four samples of human whole bloods were collected from healthy volunteers; these samples were provided by Xi'an zhenghe hospital. All samples were collected immediately following blood sampling for routine medical 
examination, using the needle from a blood collection set. Sodium heparin was used as anticoagulant in both collection tubes. The samples were maintained at $-20{ }^{\circ} \mathrm{C}$ in cleaned plastic tubes with colorless stoppers.

\section{Apparatus}

A model AFS-2202 double-channel non-dispersive atomic fluorescence spectrometer fitted with a programmable intermittent reactor (Beijing Haiguang Instrument Co., Beijing, China) was employed throughout this work. The Cd hollow cathode lamp (HCL) that was specially designed for AFS was used as the radiation source. This type of HCL gave improved stability and a longer lifetime. A solar blind photomultiplier was used as the detector in the nondispersive detection system. An electrically heated quartz furnace was used as the atomizer. The operating parameters used for the AFS instrument are given in Table 1.

Table 1. The operating parameters of the non-dispersive AFS instrument

\begin{tabular}{lc}
\hline Parameter & $\mathrm{Cd}$ \\
\hline Applied voltage of PMT/ V & 320 \\
Atomizer temperature $/{ }^{\circ} \mathrm{C}$ & 850 \\
Atomizer height $/ \mathrm{mm}$ & 10 \\
HCL applied current/(mA) & 60 \\
Flow rate of carrier gas $(\mathrm{Ar}) /\left(\mathrm{mL} \mathrm{min}^{-1}\right)$ & 600 \\
Flow rate of shield gas $(\mathrm{Ar}) /\left(\mathrm{mL} \mathrm{min}{ }^{-1}\right)$ & 1000 \\
Read mode & Peak area \\
\hline
\end{tabular}

A modified intermittent-flow reactor similar to that described previously ${ }^{13}$ was employed with the following modifications: a small-bore Tygon ${ }^{\circledR}$ tubing (1/32 inch i.d.) was used instead of the manufacturer's peristaltic pump tubing (1/16 inch i.d.) to reduce the propelled amounts of samples; a new-channel was added to propel the enhancer solution (Figure 1). A sampling coil of 30-cm was used. A Tygon ${ }^{\circledR}$ tubing ( 1 inch i.d.) $6 \mathrm{~cm}$ in length was used as mixing coil to decrease the diffusion of $\mathrm{Cd}$ volatile species. Thiourea and $\mathrm{Co}^{2+}$ were used as enhancers and added on-line to samples and standards. Sample/standard solutions were mixed with enhancers in a first confluence point; and then those solutions were mixed with aqueous $\mathrm{KBH}_{4}$ in a second confluence point. Cadmium hydride was generated in this intermittent-flow reaction system. Figure 1 schematically illustrates the system used in this work and the working program of the intermittentflow reactor is described in Table 2.

An ICP-MS instrument (X7, Thermo Elemental, USA) was used for optimizing the sonication parameters and for

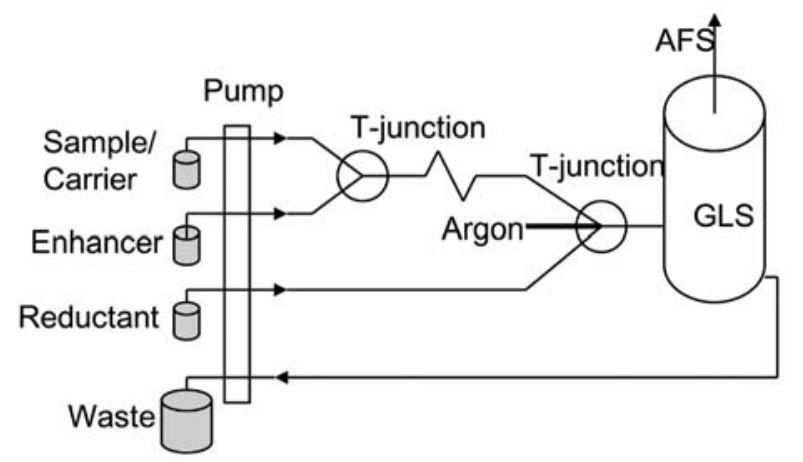

Figure 1. Schematic diagram of the modified intermittent-flow reactor.

Table 2. Working program for the intermittent- flow reactor

\begin{tabular}{llcl}
\hline Step & Flow rate/(mL min $\left.{ }^{-1}\right)$ & time/(s) & Function \\
\hline 1 & $\begin{array}{l}\text { Sample: } 1.5 \\
\text { Enhancer: } 1.5\end{array}$ & 6 & Pumping of sample solution \\
& Reductant: 1.5 & & \\
\hline 2 & $\begin{array}{l}\text { Sample: } 0 \\
\text { Enhancer: } 0\end{array}$ & 3 & $\begin{array}{l}\text { Sample tube transferred to } \\
\text { carrier solution }\end{array}$ \\
Reductant: 0 & & \\
\hline $3 \quad$ & Carrier solution: 2 & 16 & $\begin{array}{l}\text { Carrier solution transports } \\
\text { sample solution through the } \\
\text { Enhancer: } 2\end{array}$ \\
Reductant: 2 & & $\begin{array}{l}\text { reactor and cleaning of the } \\
\text { sample tube }\end{array}$ \\
\hline $4 \quad$ Sample: 0 & 3 & $\begin{array}{l}\text { Sample tube transferred to the } \\
\text { next sample }\end{array}$ \\
Enhancer: 0 & & \\
Reductant: 0 & &
\end{tabular}

comparison of results with those obtained by the developed method. The instrument was operated in a Class-1000 clean, air-conditioned laboratory kept at a temperature of $20 \pm 2{ }^{\circ} \mathrm{C}$. The operating parameters for ICP-MS were optimized prior to determination with a solution containing $1 \mathrm{ng} \mathrm{mL}-1$ of $\mathrm{Be}, \mathrm{Co}, \mathrm{In}, \mathrm{Ce}$, and $\mathrm{U}$. The operating conditions are listed in Table 3. The measured isotopes were ${ }^{111} \mathrm{Cd}$ and ${ }^{114} \mathrm{Cd}$ and $5 \mathrm{ng} \mathrm{mL}-1$ of $\mathrm{Rh}$ in the final test solutions was used as internal standard during ICP-MS measurement. The isobaric overlap between ${ }^{114} \mathrm{Cd}$ and ${ }^{114} \mathrm{Sn}$ was auto-corrected by the mathematical treatment software of the instrument.

A $100 \mathrm{~W}, 40 \mathrm{kHz}$ ultrasonic cleaner-bath (KQ-218, Kunshan ultrasonic instrument Co. Shanghai, China) was used for extraction of cadmium from whole blood.

\section{Procedures}

\section{Optimization of sonication parameters}

A $0.10 \mathrm{~mL}$ of GBW 09132, GBW09133 and GBW09134 whole blood CRMs were accurately transferred into $5 \mathrm{~mL}$ of medical polypropylene centrifuge tube containing $0.9 \mathrm{~mL}$ 
Table 3. Operating parameters of ICP-MS

\begin{tabular}{ll}
\hline Parameter & Setting \\
\hline RF power/W & 1350 \\
Plasma gas flow rate/(L min $\left.{ }^{-1}\right)$ & 14 \\
Auxiliary gas flow rate/( $\left.\mathrm{L} \mathrm{min}^{-1}\right)$ & 1.0 \\
Nebulizer gas flow rate/(L min $\left.{ }^{-1}\right)$ & 0.88 \\
Nebulizer & Meinhard, glass, concentric \\
Spray chamber temperature/ ${ }^{\circ} \mathrm{C}$ & 3 \\
Sampler cone & Nickel, $1.0 \mathrm{~mm}$ orifice diameter \\
Skimmer cone & Nickel, $0.7 \mathrm{~mm}$ orifice diameter \\
Acquisition mode & Peak jumping \\
Number of sweeps & 50 \\
Channels dwell time per sweep/ms & 10 \\
Channels per mass & 3 \\
\hline
\end{tabular}

of corresponding extractant solution (diluted $\mathrm{HNO}_{3}$ or $\mathrm{HCl}$ solutions). Then the sample-extractant mixture was sonicated at room temperature by varying sonication parameters. After sonication, it was added $1 \mathrm{~mL}$ of $10 \mathrm{ng} \mathrm{mL} \mathrm{mL}^{-1} \mathrm{Rh}$ internal standard solution, the supernatant liquid was separated from the solid phase by centrifugation for about 3-5 min at $8000 \mathrm{rpm}$ and then transferred the clear supernatant to another centrifuge tube for measurements by ICP-MS. Analytical blanks were also prepared using this same procedure without any sample. The percentage recovery of cadmium after ultrasound-assisted extraction was calculated using the found value and certified value ratio.

\section{Optimization of hydride generation conditions}

Hydride generation was conducted using an intermittentflow mode with a flow rate of $1.5 \mathrm{~mL} \mathrm{~min}{ }^{-1}$ for both sample and reagent solutions. The operation of the pump was programmed in four steps for each measurement. In the beginning of first step, the sample tube was placed in the test solution, and then the pump propelled the solution into the sampling coil. Second, the pump stopped for $3 \mathrm{~s}$ thus allowing the sample tube to be transferred to the carrier solution. At this stage, the sample stayed in the sampling coil that was in front of the confluence point of the manifold and consequently no reaction occurred between the sample solution and the reductant. Third, the carrier solution was propelled, pushing the sample and the reductant into the mixing coil and gas-liquid generator. At this stage, the volatile species were formed and transported to the quartz furnace. A heating wire, which was coiled around the upper end of the quartz tube, ignited the mixture of hydrogen evolved from the chemical reaction to form a hydrogen-argon-air entrained micro-flame in which the hydride of cadmium was atomized determined by AFS. In the final step, the pump was stopped again and made ready for the next determination. For the optimization of response, $2 \mathrm{ng} \mathrm{mL} \mathrm{m}^{-1} \mathrm{Cd}$ was used throughout this study, if not otherwise stated.

\section{HG-AFS determination of Cd after ultrasound-assisted preparation (method A)}

A volume of $0.10 \mathrm{~mL}$ of whole blood was accurately transferred into a $5 \mathrm{~mL}$ of medical polypropylene centrifuge tube containing $0.9 \mathrm{~mL}$ of $4 \% \mathrm{HNO}_{3}(\mathrm{v} / \mathrm{v})$. Then the sample-extractant mixture was sonicated at room temperature for 5-8 $\mathrm{min}$. After sonication, the supernatant liquid was separated from the solid phase by centrifugation for about 3-4 $\mathrm{min}$ at $8000 \mathrm{rpm}$; and the clear supernatant was used for analysis by HG-AFS. Blanks and standards were prepared in a similar manner with deionized water and diluted $\mathrm{Cd}(\mathrm{II})$ aqueous standard solutions.

\section{ICP-MS determination of Cd after ultrasound-assisted preparation (method $B$ )}

A volume of $0.10 \mathrm{~mL}$ of whole blood was accurately transferred into a $5 \mathrm{~mL}$ of medical polypropylene centrifuge tube containing $0.9 \mathrm{~mL}$ of $4 \% \mathrm{HNO}_{3}(\mathrm{v} / \mathrm{v})$. Then the sampleextractant mixture was sonicated at room temperature for 5-8 min. After sonication, it was added $1 \mathrm{~mL}$ of $10 \mathrm{ng} \mathrm{mL}^{-1}$ $\mathrm{Rh}$ internal standard solution, the supernatant liquid was separated from the solid phase by centrifugation for about 3-5 min at $8000 \mathrm{rpm}$ and then transferred the clear supernatant to another centrifuge tube for the analysis by ICP-MS. Blanks and standards were prepared in a similar manner with deionized water and diluted Cd (II) aqueous reference standard solutions.

\section{ICP-MS determination of Cd after dilution (method C)}

A volume of $0.10 \mathrm{~mL}$ of whole blood samples were analysed by ICP-MS directly after simple 50 -fold dilution with the mixed diluent of $0.2 \%(\mathrm{v} / \mathrm{v})$ Triton $\mathrm{X}-100+0.02 \%$ $\mathrm{HNO}_{3}(\mathrm{~m} / \mathrm{v})+5 \mathrm{ng} \mathrm{mL}{ }^{-1} \mathrm{Rh}$. Blanks and standards were prepared in a similar manner with deionized water and diluted $\mathrm{Cd}(\mathrm{II})$ aqueous reference standard solutions.

\section{Results and Discussion}

\section{Optimization of the conditions of ultrasound-assisted extraction}

The effect of experimental parameters, such as the composition of the extractant, sonication time, the amount 

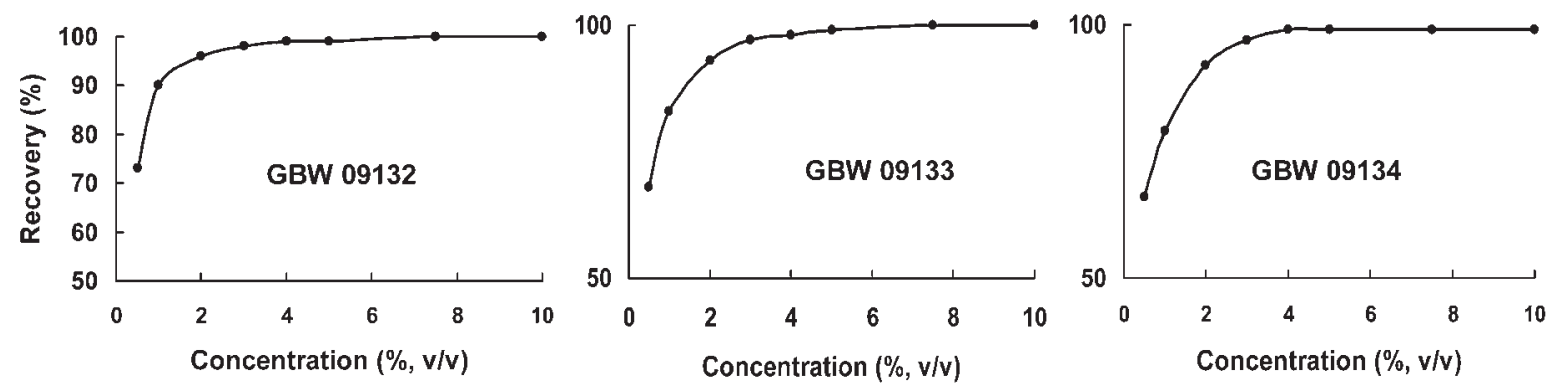

Figure 2. Effect of $\mathrm{HNO}_{3}$ concentrations on the extraction efficiency of Cd in whole blood CRMs. Sonication time: 6 min.

of sample, on the extraction efficiency of $\mathrm{Cd}$ were optimized using whole blood CRMs. In order to decrease the dilution factor, the volume of extractant was fixed in $0.9 \mathrm{~mL}$ and in order to eliminate the influence of acidity on the generation efficiency of the volatile cadmium species, the clear supernatant liquid was determined by ICP-MS. The recovery of cadmium in CRMs after ultrasound-assisted extraction was calculated using the following equation: Recovery $(\%)=[$ Found value/ Certified value $] \times 100$.

The composition of the liquid extractant was an important parameter for the extraction of $\mathrm{Cd}$ from blood. The influence of the nitric acid concentration on the extraction efficiency of $\mathrm{Cd}$ was studied in a univariate way by fixing the other variable parameters. Acid concentrations between 0 and $10 \%$ m/v were studied; and the results are shown in Figure 2. It can be clearly seen that the extraction efficiency of $\mathrm{Cd}$ in three CRMs increased with increasing acid concentrations; a full extraction efficiency (recovery $>98 \%$ ) being reached for nitric acid concentrations higher than $3 \% \mathrm{v} / \mathrm{v}$. Therefore, $4 \% \mathrm{v} / \mathrm{v} \mathrm{HNO}_{3}$ was selected as optimized extractant for further experiments. Hydrochloric acid can be used instead of nitric acid with similar results.

The sonication time was other important parameter for the extraction of $\mathrm{Cd}$ from blood. The influence of sonication time on the extraction efficiency of cadmium from whole blood is shown in Figure 3. It was found that the extraction efficiency of cadmium increased with increasing sonication time from 1 to $5 \mathrm{~min}$ and reached plateau. The sonication time of 6 min was found to be sufficient for the quantitative extraction of cadmium from blood.

In this work, extraction efficiency of cadmium using different samples volumes $(0.050,0.10,0.20$ and $0.30 \mathrm{~mL})$ for sonication was investigated. Extraction concentration and volume $\left(0.9 \mathrm{~mL}\right.$ of $\left.4 \% \mathrm{v} / \mathrm{v} \mathrm{HNO}_{3}\right)$, sonication time (6 min) were kept constant in all these experiments. These studies indicate that quantitative recovery with good precision for cadmium for blood CRMs was achieved when the sample volume was 0.10 and $0.20 \mathrm{~mL}$. Hence sample volume of $0.10 \mathrm{~mL}$ was used in further experiments.

Otherwise, the experimental results revealed that substitution of EDTA as the anticoagulant for blood did not affect the extraction efficiency of cadmium from blood; besides, the presence of trace amount of EDTA did not influence on the determination of cadmium by HG-AFS.

\section{Optimization of chemical variables}

The use of $\mathrm{KOH}$ medium for $\mathrm{KBH}_{4}$ solution is adopted to stabilize the reagent by avoiding its adverse reaction with water during storage. However, $\mathrm{KOH}$ concentration will affect the acidity of the reaction mixture; and acidity of the solution is an important parameter that has great influence on the generation efficiency of the volatile cadmium species. ${ }^{15}$ Nevertheless, the constant acidity of sample was chosen as the optimized extractant during the process of sample preparation with ultrasound-assisted
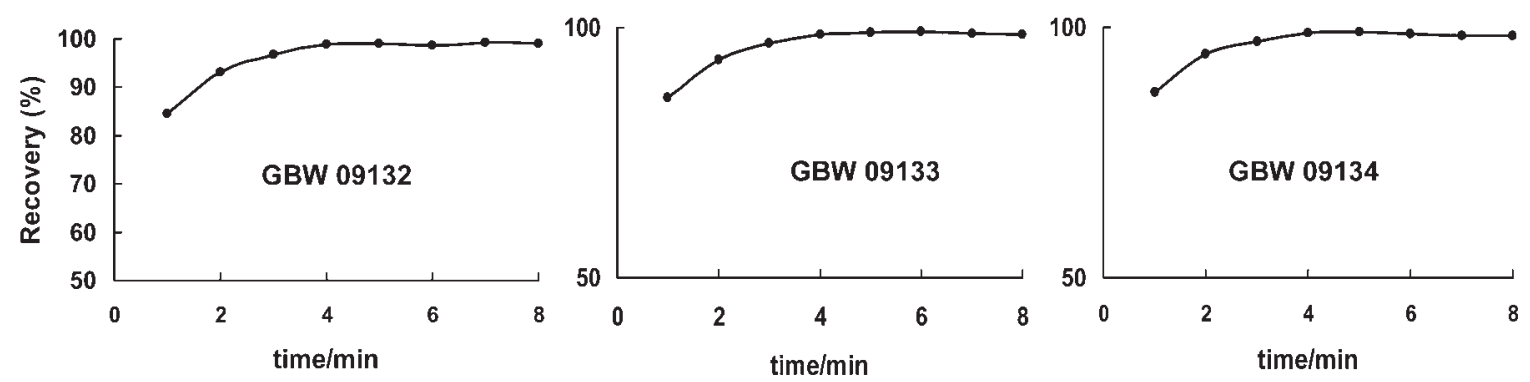

Figure 3. Effect of sonication time on the extraction efficiency of $\mathrm{Cd}$ in whole blood CRMs. Extractant: $4 \% \mathrm{HNO}_{3}(\mathrm{v} / \mathrm{v})$. 
extraction in this work, hence the acidity of the reaction mixture was adjusted by using $\mathrm{KOH}$ in $\mathrm{KBH}_{4}$ solution. Using $3.0 \% \mathrm{~m} / \mathrm{v} \mathrm{KBH}_{4}$ as reductant, it was studied the influence of $\mathrm{KOH}$ concentration in this solution on the atomic fluorescence signal of cadmium and the results are shown in Figure 4. It can be clearly seen that there is a plateau in the range of $0.15-0.30 \% \mathrm{~m} / \mathrm{v} \mathrm{KOH}$. Remarkable drop of the signal was observed with further increase of the $\mathrm{KOH}$ concentration when exceeding $0.50 \%(\mathrm{~m} / \mathrm{v})$. This effect might be attributed to the fact that the excessive increase of $\mathrm{KOH}$ concentration will definitely decrease the acidity of the reaction mixture and hence the reaction rate of hydride generation. In this work, a $0.2 \% \mathrm{~m} / \mathrm{v} \mathrm{KOH}$ solution was thus employed to prepare $\mathrm{KBH}_{4}$ solution. It should be pointed out that the results reported here are only valid when the ratio of the propelling rate of the sample to that of the reductant is the same as or close to the value suggested in this paper. Besides, the optimum range of $\mathrm{KOH}$ concentration can be shifted with the use of various concentrations of $\mathrm{KBH}_{4}$ as reductant.

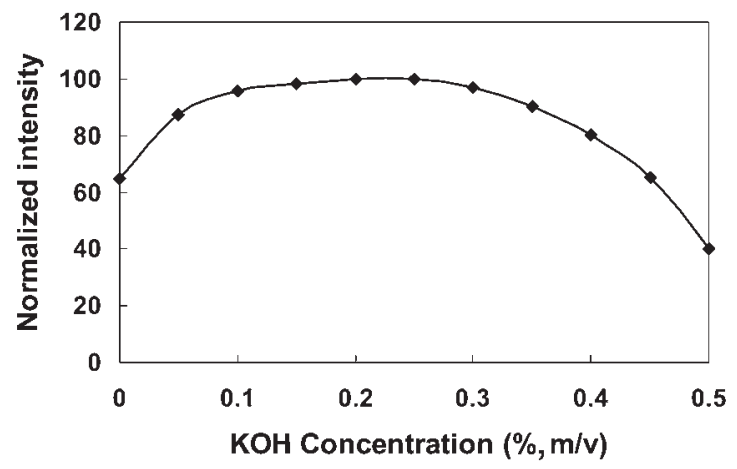

Figure 4. Effect of $\mathrm{KOH}$ concentration on the cadmium atomic fluorescence signal. Conditions: $2 \mathrm{ng} \mathrm{mL}^{-1}$ of $\mathrm{Cd} ; 3.0 \% \mathrm{~m} / \mathrm{v} \mathrm{KBH}_{4}$; Enhancer: $1.5 \% \mathrm{~m} / \mathrm{v}$ thiourea- $1 \mathrm{mg} \mathrm{L}^{-1} \mathrm{Co}^{2+}$; The operating parameters of the non-dispersive AFS instrument, see Table 1; Working program for the intermittent flow reactor, see Table 2.

The effects of other chemical variables on the cadmium atomic fluorescence signal by non-dispersive AFS were reported in previous publications. ${ }^{15-17,20}$ In this work, the influences of the concentrations of $\mathrm{KBH}_{4}$ and enhancer on the atomic fluorescence intensities were also investiged because of the use of a modified intermittent-flow reactor. The relationship between the concentration of $\mathrm{KBH}_{4}$ and the peak area signal is shown in Figure 5. Under the optimized concentrations of $\mathrm{KOH}$ and $\mathrm{HNO}_{3}$, when $\mathrm{KBH}_{4}$ solution concentrations were increased from 1 to $2.5 \%(\mathrm{~m} / \mathrm{v})$, the $\mathrm{Cd}$ signal intensities increased sharply; and the peak area signals remained constant when the concentration of $\mathrm{KBH}_{4}$ was in the range of 3 to $4 \%(\mathrm{~m} / \mathrm{v})$. When the concentration of $\mathrm{KBH}_{4}$ was higher than $4 \%(\mathrm{~m} / \mathrm{v})$, the $\mathrm{Cd}$ signal intensities were slightly suppressed. Taking into account that blood matrix tends to foam; it was decided to use as low as possible $\mathrm{KBH}_{4}$ concentration: A concentration of $3 \%(\mathrm{~m} / \mathrm{v}) \mathrm{KBH}_{4}$ was established as suitable.

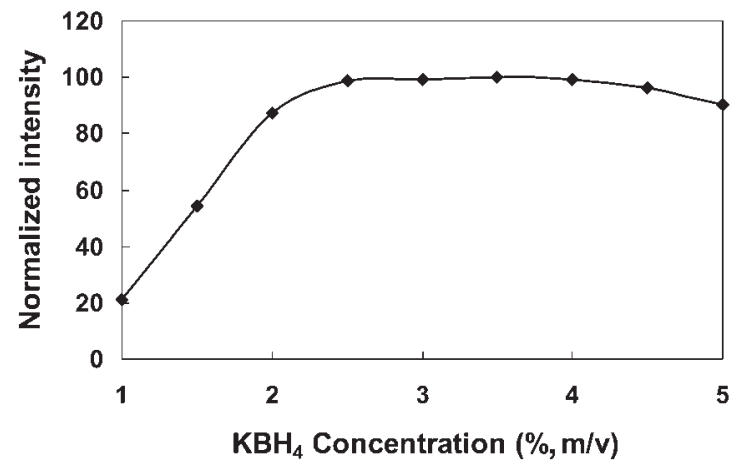

Figure 5. Effect of $\mathrm{KBH}_{4}$ concentration on the cadmium atomic fluorescence signal. Conditions: $2 \mathrm{ng} \mathrm{mL}^{-1}$ of Cd; Enhancer: $1.5 \% \mathrm{~m} / \mathrm{v}$ thiourea-1mg $\mathrm{L}^{-1} \mathrm{Co}^{2+}$. The operating parameters of the non-dispersive AFS instrument, see Table 1; Working program for the intermittent flow reactor, see Table 2 .

The antifoam "B" was found to be sufficient to eliminate foaming of the sample mixture as it reacted to $\mathrm{KBH}_{4}$. Excessive foaming reduces the effectiveness of the gas-liquid separator. The experimental results showed that the presence of $0.01 \%(\mathrm{v} / \mathrm{v})$ antifoam " $\mathrm{B}$ " in $\mathrm{KBH}_{4}$ could entirely eliminate the foam in gas-liquid separator. In this work, antifoam "B" was dissolved in $\mathrm{KBH}_{4}$ solution and the concentration of $0.01 \%(\mathrm{v} / \mathrm{v})$ was used as optimal.

Guo et al. ${ }^{15}$ reported that the presence of thiourea together with cobalt further enhanced the generation efficiency of the volatile cadmium species. In this work, the influences of the concentration of thiourea and $\mathrm{Co}^{2+}$ on the atomic fluorescence intensities were investigated. The experimental results reveal that the enhancement reagents did not significantly improve the hydride generation efficiency of $\mathrm{Cd}$, in the presence of thiourea and cobalt ions, the sensitivity of $\mathrm{Cd}$ was only increased $50 \%$. However, it is important to notice that the use of thiourea and $\mathrm{Co}^{2+}$ may reduce the interferences caused by some coexisting ions (e.g. $\mathrm{Fe}^{3+}, \mathrm{Zn}^{2+}$ and $\mathrm{Cu}^{2+}$ ). A concentration of $1.5 \%$ $\mathrm{m} / \mathrm{v}$ thiourea and $1 \mathrm{mg} \mathrm{L}^{-1} \mathrm{Co}^{2+}$, added on-line to samples and standards, was recommended in this work.

\section{Interferences studies}

Blood is a highly specialized biological fluid composed of many different kinds of components; organic matter (e.g. proteins, sugars and lipids), inorganic ions and water are the major portion in blood sample. When blood was treated with mineral acid at the step of sample preparation, a relatively 
Table 4. Analytical results of cadmium in real samples and CRMs (mean \pm standard deviation, $n=3$ )

\begin{tabular}{|c|c|c|c|c|}
\hline \multirow[t]{2}{*}{ Samples } & \multicolumn{4}{|c|}{$\mathrm{Cd} /\left(\mu \mathrm{g} \mathrm{L}^{-1}\right)$} \\
\hline & Method $\mathrm{A}^{c}$ & Method $\mathrm{B}^{d}$ & Method C ${ }^{e}$ & Certified value \\
\hline GBW 09132 & $1.06 \pm 0.12$ & $1.03 \pm 0.07$ & $0.97 \pm 0.18$ & $1.05 \pm 0.17$ \\
\hline GBW 09133 & $4.36 \pm 0.24$ & $4.27 \pm 0.17$ & $4.13 \pm 0.29$ & $4.22 \pm 0.33$ \\
\hline GBW 09134 & $8.64 \pm 0.37$ & $8.76 \pm 0.29$ & $8.47 \pm 0.41$ & $8.84 \pm 0.49$ \\
\hline Bovine blood & $0.19 \pm 0.04$ & $0.21 \pm 0.03$ & $0.23 \pm 0.09$ & ------ \\
\hline Blood $1^{a}$ & $0.67 \pm 0.10$ & $0.69 \pm 0.07$ & $0.64 \pm 0.12$ & ------ \\
\hline Blood $2^{a}$ & $0.83 \pm 0.09$ & $0.81 \pm 0.07$ & $0.79 \pm 0.09$ & ------- \\
\hline Blood $3^{b}$ & $1.01 \pm 0.12$ & $1.00 \pm 0.09$ & $0.97 \pm 0.13$ & ------- \\
\hline Blood $4^{b}$ & $1.23 \pm 0.11$ & $1.19 \pm 0.08$ & $1.16 \pm 0.13$ & ------- \\
\hline
\end{tabular}

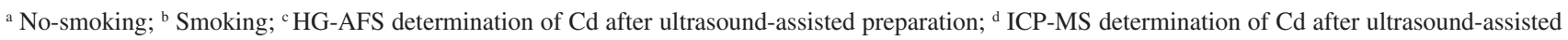

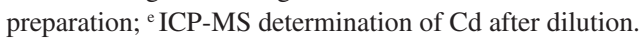

large amount of organic matter agglutinated and deposited and only a small quantity of organic matter remained in the supernatant liquid. In this work, the influence of the residual organic matter in the supernatant liquid on the determination of cadmium was studied. The experiments has shown that the bulk foam is formed and carried into the atomizer by carrier gas when the supernatant liquid is mixed with aqueous $\mathrm{KBH}_{4}$ and the signal of cadmium was intensely depressed, further experiments indicated that the residual organic matter did not interfere with the hydride generation but with the transport and atomization of the hydrides in the hydrogen-argon-air entrained microflame. In order to limit formation of foam, a concentration of $0.01 \% \mathrm{v} / \mathrm{v}$ antifoam $\mathrm{B}$, mixed into aqueous $\mathrm{KBH}_{4}$, was recommended in this work. It has been well documented that the transition metals can severely suppress the generation efficiency of the volatile cadmium species ${ }^{15}, 20$, which is most pronounced for $\mathrm{Cu}^{2+}, \mathrm{Pb}^{2+}, \mathrm{Zn}^{2+}$ and $\mathrm{Fe}^{3+}$. In blood samples, transition metals are another serious interfering component. In this work, the potential interfering effects of 10 metals at various concentration levels were thus investigated. The results show that $100 \mathrm{mg} \mathrm{L}^{-1} \mathrm{Fe}^{3+}$, $5 \mathrm{mg} \mathrm{L}^{-1} \mathrm{Zn}^{2+}, 1 \mathrm{mg} \mathrm{L}^{-1} \mathrm{As}^{3+}, \mathrm{Sb}^{3+}, \mathrm{Mn}^{2+}, \mathrm{Ni}^{2+}, \mathrm{Cr}^{6+}, \mathrm{Se}^{6+}$, $0.2 \mathrm{mg} \mathrm{L}^{-1} \mathrm{Cu}^{2+}$ and $0.1 \mathrm{mg} \mathrm{L}^{-1} \mathrm{~Pb}^{2+}$ did not interfere with the determination of $2 \mathrm{ng} \mathrm{mL}^{-1}$ of $\mathrm{Cd}$ under the established chemical conditions within the error range of $\pm 5 \%$. The contents of the aforementioned metals in the extracted blood are well within the tolerant concentration range by using the proposed sample preparation protocol. Therefore, the extracted blood could be analyzed directly using simple aqueous reference standard calibration techniques.

\section{Evaluation of performance of the procedure}

The analytical characteristic data were determined using the recommended conditions. The limit of detection (LOD) and limit of quantification (LOQ) of the proposed procedure were 0.08 and $0.26 \mu \mathrm{g} \mathrm{L}^{-1}$, calculated from three and ten times the standard deviations of eleven runs of blank blood sample (bovine blood) with low $\mathrm{Cd}$ content $\left(0.2 \mu \mathrm{g} \mathrm{\textrm {L } ^ { - 1 }}\right.$ $\mathrm{Cd}$, tenfold diluted). The relative standard deviation (RSD, $n=7$ ) varied between $3-10 \%$ (between-run) at a 1-8 $\mu \mathrm{g} \mathrm{L}^{-1}$ cadmium level in blood. In order to further evaluate the feasibility of the proposed method for the determination of $\mathrm{Cd}$, three Chinese clinical certified reference materials (GBW 09132, 09133 and 09134), one bovine whole blood and four human whole bloods were determined using the present method (method A) and compared with ICP-MS methods (methods B and C). The results are shown in Table 4. It can be seen that the concentrations of cadmium in the certified reference materials obtained by the present method were in good agreement with the certified values. Furthermore a comparison of the independently analytical methods further demonstrated that the present method was reliable for the determination of trace cadmium in blood samples.

\section{References}

1. Jarup, L.; Berglund, M.; Elinder, C. G.; Nordberg, G.; Vahter, M.; Scand. J. Work, Environ. Health, 1998, 24, 1.

2. Friberg, L.; Elinder, C.G.; Kjellstrom, T.; Nordberg, G. F.; Cadmium and Health: A Toxicological and Epidemiological Appraisal, CRC Press: Boca Raton Florida, 1985.

3. Il'yasova, D.; Schwartz,G. G.; Toxicol. Environ. Chem., 2005, 207, 179.

4. International Agency for Research on Cancer (IARC) Monographs on the Evaluation of the Carcinogenic Risks to Humans-Beryllium, Cadmium, Mercury, and Exposures in the Glass Manufacturing Industry, vol. 58, WHO: Lyon, 1993.

5. Cerny, E. A.; Bhattacharyya, M. H.; Anal. Biochem., 2003, 314, 180. 
6. Tsalev, D. L.; Lampugnani, L.; Georgieva, R.; Chakarova, K. K.; Petrov Jr., I. I.; Talanta, 2002, 58, 332.

7. Campillo, N.; Vinñas, P.; García, I. L.; Córdoba, M. H.; Anal. Chim. Acta, 1999, 390, 207.

8. Bruhn, C. G.; Neira, J. Y.; Valenzuela, G. D.; Nóbrega, J. A.; Talanta, 1999, 48, 537

9. Nixon, D. E.; Neubauer, K. R.; Eckdahl, S. J.; Butz, J. A.; Burritt, M. F.; Spectrochim. Acta, Part B, 2004, 59, 1377.

10. Zhang, Z. W.; Shimbo, S.; Ochi, N.; Eguchi, M.; Watanabe, T.; Moon, C. S.; Ikeda , M.; Sci. Total Environ., 1997, 205, 179.

11. Nixon, D. E.; Moyer, T. P.; Spectrochim. Acta, Part B, 1996, $51,13$.

12. Guo, X. W.; Lab. Robot. Autom. 2000, 12, 67.

13. Li, Z. X.; Guo, Y.A.; Talanta, 2005, 65, 1318.

14. Wang, J. H.; Yu, Y. L.; Du, Z.; Fang, Z. L.; J. Anal. At. Spectrom., 2004, 19, 1559.

15. Guo, X.W.; Guo, X. M.; Anal. Chim. Acta, 1995, 310, 377.

16. Lu, Y. K.; Sun, H. W.; Yuan, C. G.; Yan, X. P.; Anal. Chem., 2002, 74, 1525.

17. Sun, H. W.; Suo, R.; Anal. Chim. Acta, 2004, 509, 71.

18. Li, G.; Wu, L.; Xin, J. J.; Hou, X. D.; J. Anal. At. Spectrom., 2004, 19, 1010
19. Duan, T. C.; Song, X. J.; Jin, D.; Li, H. F.; Xu, J. W.; Chen, H. T.; Talanta, 2005, 67, 968.

20. Li, Z. X.; Zhou, L. P.; Anal. Sci., 2006, 22, 123.

21. Luque-García, J. L.; Luque de Castro, M. D.; Trends Anal. Chem., 2003, 22, 90 .

22. Munoz, R. A. A.; Kolbe, M.; Siloto, R. C.; Oliveira, P. V.; Angnes, L.; J. Braz. Chem. Soc., 2007, 18, 410.

23. Capelo, J. L.; Lavilla, I.; Bendicho, C.; J. Anal. At. Spectrom., 1998, 13, 1285.

24. Lima, E. C.; Barbosa Jr., F.; Krug, F. J.; Silva, M.M.; Vale, M. G. R.; J. Anal. At. Spectrom., 2000, 15, 995.

25. Ruiz-Jiménez, J.; Luque-García, J. L.; Luque de Castro, M. D.; Anal. Chim. Acta., 2003, 480, 231.

26. Krishna, M. V. B.; Arunachalam, J.; Anal. Chim. Acta., 2004, 522,179

27. Caballo-Lòpez, A.; Luque de Castro, M. D.; Talanta, 2007, 71, 2074.

Received: January 13, 2008 Web Release Date: August 20, 2008 